Review

\title{
Political Instability and Firm Performance: A Microeconomic Evidence from Ivory Coast
}

\author{
${ }^{1}$ Ernest Ouédraogo, ${ }^{1}$ Ibrahim Ouédraogo and ${ }^{2}$ Emmanuel Lompo \\ ${ }^{1}$ Department of Economics, University Ouaga 2, Burkina Faso \\ ${ }^{2}$ Department of Political Science, Laval University, Canada
}

\author{
Article history \\ Received: 26-07-2020 \\ Revised: 21-10-2020 \\ Accepted: 23-10-2020 \\ Corresponding Author: \\ Emmanuel Lompo \\ Department of Political Science, \\ Laval University, Canada \\ Email: emmalomp@gmail.com
}

\begin{abstract}
In this paper, we investigate how political instability affects firms' performance in Ivory Coast. Using data from the World Bank's 2016 survey of 361 firms in Ivory Coast, we perform a robust endogenous treatment model to assess the causal impact of political instability on firm productivity. The results indicate that political instability is statistically significant and negatively associated with firm performance. More specifically, firms that perceive political instability as an obstacle have XOF 511 million less annual sales than those which do not perceive political instability as an obstacle. Therefore, the government of Ivory Coast should develop strategies to reduce political instability in order to ensure efficient and performing firms.
\end{abstract}

Keywords: Political Instability, Firm Performance, Ivory Cost

\section{Introduction}

The economic literature basically distinguishes three major sources of corporate performance namely the innovation and imperfect competition (Acs and Audretsch, 1987; Schumpeter, 1976), the resource development including labour and production processes (Goldberg and Rai, 1996; Makhija, 2003) and the business environment (Dollar et al., 2005). While the first two determinants of firms performance have been extensively studied in the literature, the role of the business environment, particularly political instability, remains difficult to capture empirically, as despair being a major development concern in developing countries for several years.

Over the last decades, political instability in developing countries has been two to six times higher than in industrialized countries, leading to an economic volatility (Pallage et al., 2006). In terms of economic performance, Sub-Saharan African economies are subject to high volatility as well in terms of firms' performance. The recent financial and economic crisis of 2008-2009 has worsened macroeconomic stability and global growth prospects. Indeed, the deepening global recession, rising unemployment and high volatility of commodity prices and consumption in 2008-2009 severely affected progress towards the Millennium Development Goal of poverty reduction.
Hence, it is central for developing countries to assess the impact of political instability on the firms' performance. Especially how companies can perform well when the economy in under political instability. This issue is particularly important for practitioners and policy makers because of its links to economic transformation (Söderbom et al., 2002).

In Ivory-Coast, the site of our analysis, political instability has been a major issue in the previous decade. Historically, the Ivorian political crisis began with a coup d'état in 1999 against President Konan Bedié. followed by an attempted coup in 2002 that lasted more than 10 years with a war between rebels and loyalists. From 2002 to 2010, the country was divided in two due to an armed rebellion. The country was involved in a long civil war between the rebels, mostly muslim and the government, mostly christian. Since then, peace agreements have alternated with an upsurge in violence in 2010. Since then, the country has slowly moved towards a political stability. Over the past 20 years, the average political stability index in Ivory Cost has averaged -1.36 according to the World Bank database (Fig. 1 in appendix).

Most enterprises consider political instability to be the main obstacle for their development. For instance, about $80 \%$ of the companies surveyed in the World Bank's 2016 Enterprises survey consider political instability as a very important obstacle to their business 
growth in Ivory Coast (Table 1). With the return of political stability and peace, accompanied by policies to encourage social and economic activities, Ivory Coast has begun to recover and grow rapidly. The national development plan, adopted for the period 2016-2020, aims to achieve a state of emergency by 2020. To achieve that goal, it was essential to maintain the recent good growth performance through effective policies. To this end, the Government has adopted new laws to ensure a business and policy environment that attracts investors and stimulates business activity.

However, understanding how the political instability of the recent years has affected business performance will give policymakers excellent tools to decide and implement policies. The objective of this paper is to help fill this gap by using microeconomic data from the World Bank's Ivory Cost Enterprises Survey to assess the impact of political instability on firms' performance. This survey is suitable database for three reasons: (1) Detailed information on the sales of enterprises and the obstacles encountered, (2) the survey covers all sizes of enterprises: Small, medium and large (3) the survey covers enterprises throughout the country using a sampling methodology. This paper is therefore in line with the small but growing interest in the importance of the business environment in determining business performance. Previous work in this area has focused either on the macroeconomic aspect or on the alternative policy scenario and business performance (Alesina et al., 1996; Carmignani, 2003). This paper extends the work of Klapper et al. (2013) on Ivorian firms by using annual sales growth as a measure of firm performance rather than total factor productivity and the new methodology.

After estimating a cross-section OLS and an endogenous treatment effect model, we find strong evidence that political instability is associated with lower performances for firms in Ivory Cost.

The rest of the paper is presented as follows. Section 2 presents the literature review, Section 3 outlines the methodology and data, Section 4 presents the descriptive statistics. Section 5 reports and discusses the empirical results and section 6 concludes.

\section{Literature Review}

This paper is related to the theoretical and empirical literature on the economic consequences of violence and civil conflicts and closely related to Hallward-Driemeier and Rijkers (2011). Political instability is among the major determinant of growth (Barro, 1991; Alesina et al., 1996). Until recently, study on this topic has been dominated by crosscountry and cross-region analyses (Cerra and Saxena, 2008; Abadie and Gardeazabal, 2003). There is strong relationship between political sphere, business environment and economic decisions which affect firms' activities and performance. High uncertainty in political sphere induces low investment and capital flight (Overland et al., 2005). This is an important conclusion for developing countries since most of them are characterized by high volatility of their political sphere. There has been bulk of studies on the effect of conflict and violence at macro-level, however, heterogeneity associated with individual conflicts and how to differentiate the impact on different group constitute a limit. Most of studies, to overcome data limitation, use the stock market returns as a proxy of firm performance.

In his seminal study, Alesina et al. (1996) provide an analysis on the relationship between political instability and growth. They found that period of high instability is characterized by a lower growth. Similarly, Carmignani (2003) confirms this relationship by acknowledging the negative effect of political instability on macroeconomic outcome variables. Abadie and Gardeazabal (2003) analyse the link between cease-fire ${ }^{1}$ and the returns of firms operating in Basque country relative to other firms. They conclude that it led to a negative impact on expected investment returns. Similarly, Guidolin and La Ferrara (2007) analyse how diamond firms react to a sudden end of civil war in Angola in 2002. They noticed a drop of $7 \%$ in market returns comparing to otherwise. They suggest that the effect of conflicts depend on institutional arrangements and in the case of Angola, it seems to be beneficial to diamond firms. Jong-A-Pin (2009) highlights four dimensions of political instability with the particularity of political regime being the most negatively significant to economic growth while Aisen and Vega (2011) consider that the transmission from political instability is made through lowering productivity growth and human capital. In another study, Bates et al. (2013), used data from 27 African countries, and found that presidential elections altered political incentives and thereby end up with economy growth as policy reforms were implemented.

At a micro level, studies on the relationship between firms and political instability remain scarce due to data constraints $^{2}$. Collier and Duponchel (2013), surveying firms in Liberia and Sierra Leone, find that technical regress and loss of workers' skills, during conflicts, have persistent effect on economy and firms. Ksoll et al. (2010) investigate on the relationship between violence during the 2007 Kenyan general election and exports by flower firms. The results indicate that violence drop

${ }^{1}$ Basque terrorist organization ETA declares cease fire in 1998-1999

${ }^{2}$ Most of this research focuses on analyses at the household level and on human capital outcomes 
by $38 \%$ the export volumes in this period while more sophisticated simulations notice an increase by $16 \%$ of operating costs. Klapper et al. (2013), analysing Ivorian firms using total factor productivity, find that political instability led to a drop in firm total factor productivity by $16-23 \%$ and a decline by $5-10 \%$ larger for firms that are owned by or employing foreigners. Similarly, Petracco and Schweiger (2012) confirm that political instability hinders Georgian firms' exports. Baker et al. (2016) provides the evidence that policy uncertainty increases stock price volatility and reduces investment in policy sensitive sectors in USA. In Ukraine, during the orange revolution, Earle and Gehlbach, (2015) find that firms in most supportive regions experience better performance.

\section{Data and Methodology}

\section{Data}

We use data from the 2016 round of World Bank Enterprise Survey of Ivory Cost. The sample includes 361 firms. In order to measure the political instability as an obstacle for firms, they were asked: "To what degree is political instability an obstacle to their current operations?" The response options were: "No obstacle", "Minor obstacle", "Moderate obstacle", "Major obstacle" and "Very severe obstacle". Unlike Klapper et al. (2013), we use total annual sale growth as a measure of firm performance. It was asked during the survey to each firm: "What were the establishment's total annual sales last fiscal year (2016)". Responses are continuous variables $^{3}$. Beside these two main variables, we follow Hosny (2018) by adding control variables such as age of the firms in years, experience of top manager in years, size of the firm measured by the number of full-time employee, percentage of private foreign ownership.

\section{Methodology}

To achieve the aim of capturing the effect of political instability on firms' performance, first and foremost, we use cross-sectional Ordinary Least Squares (OLS) with the ordered variable political instability. We specify the model as follows:

$$
\begin{aligned}
& Y_{i r}=\beta_{1}+\gamma_{r}+\beta_{2} P I_{i r}+\beta_{3} \text { Age }_{i r} \\
& +\beta_{4} \text { Experience }_{i r}+\beta_{5} \text { Size }_{i r}+\beta_{6} \text { PFO }_{i r}+\varepsilon_{i r}
\end{aligned}
$$

where, $P I$ stands for Political Instability and $F O$ is a dummy indicating private foreign ownership. The errors terms are captured by $\varepsilon_{i r}$ with subscript $i$ representing each firm, in a region $r$.

\footnotetext{
${ }^{3}$ We took the logarithm of total annual sales.
}

However, giving the potential endogeneity of the perception of political instability, causal interpretations of the cross section OLS's coefficient of political instability is inappropriate. The endogeneity rises especially because of unobservable variable such as political connection that can affect the perception of political instability and firm performance simultaneously.

Consequently, we rely on the two-stage endogenous treatment-regression model. The first stage consists in estimating the probability to face political instability using the following equation:

$$
\begin{aligned}
& P I_{i r}=\alpha_{1}+\theta_{r}+\alpha_{3} \text { Age }_{i r} \\
& +\alpha_{4} \text { Experience }_{i r}+\alpha_{5} \text { Size }_{i r}+\alpha_{6} \text { PFO }_{i r}+\alpha_{6} \text { Eth }_{i r}+\vartheta_{i r}
\end{aligned}
$$

where, $E t h_{i r}$ is the ethnical group used as the exclusion restriction. In fact, in the context of ethnic political parties in Cote d'Ivoire, it is likely that an individual ethnic group is correlated with his/her likelihood to face a political instability in his activities during the crisis.

In the second stage, we correct for the endogeneity by incorporating a transformation of these predicted individual probabilities from Equation (2) as an additional explanatory variable in Equation (1). This method developed by Terza, (1998) create an experimental environment using non-experimental data. It allows to consistently estimate the effect of the treatment (political instability) on the outcome (firm performance).

\section{Descriptive Statistics}

In this section, we report the descriptive statistics. Table 2 presents the sampling size of our data, indicating the representativeness of firms in Ivory Coast. In Table 3, we report the summary of statistics related to our variables.

Our main variables are total sales (measure of firm performance) and political instability index denoted PI. On average firms' total sales is 3220 million XOF. Political instability is an ordered categorical variable that range from 0 to 4 , where 0 indicates that the firm does not viewed political instability as an obstacle, 1 if it view political instability as a minor obstacle, 2 if political instability is viewed as a moderate obstacle, 3 if political instability is viewed as a major obstacle and 4 if political instability where reported as a very severe obstacle. Table 1 indicates that more than half of firms $(53,46 \%)$ viewed political instability as a very severe obstacles in their sector's activities. More than $20 \%$ of firms are owned by foreigners and the average number of employees is 17 workers. 
Table 1: Sampling size

\begin{tabular}{lr}
\hline Sampling size & Frequency \\
\hline Small (less than 10 workers) & 170 \\
Medium (between 10 and 99 workers) & 136 \\
Large (more than 99 workers) & 55 \\
\hline
\end{tabular}

Table 2: Descriptive statistics

\begin{tabular}{llllcl}
\hline Variable & Obs & Mean & Std. Dev. & Min & Max \\
\hline Total sales & 361 & $3.22 \mathrm{e}+09$ & $1.36 \mathrm{e}+10$ & 400000 & 0 \\
Size & 361 & 17.038 & 73.168 & 0 & $1.97 \mathrm{e}+11$ \\
Foreign owner & 361 & 20.202 & 37.818 & 1 & 1000 \\
Age & 361 & 63.645 & 295.97 & 0 & 89 \\
Exports & 361 & 7.487 & 22.609 & 1 & 100 \\
Experience (manager) & 361 & 19.304 & 12.271 & 1 & 52 \\
Political instability index & 361 & 3.074 & 1.486 & 0 & 4 \\
\hline
\end{tabular}

Table 3: Level political instability as an obstacle in 2016

\begin{tabular}{lcl}
\hline Level of obstacle & Number of firms concerned & Percentage of firms concerned \\
\hline Does not apply & 3 & 0,84 \\
No obstacle & 19 & 5,27 \\
Minor obstacle & 27 & 7,48 \\
Moderate obstacle & 25 & 6,92 \\
Major obstacle & 94 & 26,03 \\
Very severe obstacle & 193 & 53,46 \\
\hline
\end{tabular}

\section{Empirical Results}

This section report and discusses the empirical results. In Table 4, we present the cross-section OLS estimation. We find negative and statistically significant effect of political instability on firm performance, specifically for the firms which perceive the level of political instability as "moderate", "major" and "very severe" obstacle. On the other hand, firms that consider "minor" the level of political instability seem to not be affected by political instability. This result is consistent with previous empirical studies in different area such as Hosny $(2018$; 2020) for the case of Tunisia and Egypt. Furthermore, results indicate that experienced top managers are statistically significant for the performance of firms in Ivory Coast. Indeed, estimations show that the more experienced are the top managers, the more performant the firms are. This also confirms the fact that firm age is important in firm performance. Firm age is a proxy its experience in its activity. It means that firm acquires experience (including the experience of the top manager), pool of expertise and a certain capital (human, physical etc...) along the years which matters for its performance.

Results also indicates that the size of firm (number of permanent employees) and percentage of private foreign ownership of firm are also important in firm performance. Indeed, firm performance are less likely to be influenced by political instability when there is high percentage of private foreign ownership as most of firms located in Ivory Coast are group's subsidiaries and are most likely to be assisted. These above results are likely to be biased because of the endogeneity of political stability.

In the next section, we apply the endogenous treatment effect model (Table 5). We create a dummy variable equals 0 if a firm considers political instability as a not relevant, minor or moderate factor in its activity and 1 if a firm considers political instability as a major or very severe threat to their activity. Furthermore, we use the total annual sale rather than the growth in order to assess the impact in terms of value. Table 5 reports the results of the estimation of the endogenous treatment-regression model.

The results indicate that political instability has had a negative effect on firm annual total sales. Specifically, firms that perceive political instability as an obstacle have $5.11 \mathrm{e}+08 \mathrm{XOF}$ less in term of annual sales than firms that consider political instability not being an obstacle. The results are statistically significant. This result is consistent with previous study on the effect of political instability or violence on firm performance. Unlike this study, Klapper et al. (2013) consider the productivity as the best measure of firms' performance. They find evidence that political instability and conflict reduces firm TFP substantially. Our results are in line with this finding in manner that a decrease in firm TFP automatically affects the total sales. Regarding the nature 
of the conflict which spurred the increasing of antiforeigner sentiments, foreign firms have been disproportionally affected by distortions in their activities. The main reasons of this negative effect of political instability on firm performance are: (1) Loss due to looting and extorsion (2) decrease of productivity due security and (3) demand changes. These reasons affect more foreign firm installed in Ivory Coast than domestic firms since investments are flying out of the country.

The intensification of inequality and social discord might feed the risk of conflict and political instability reoccurrence. Understanding that stability is an important factor, for business development and firms, especially in the case of Ivory Coast (Fig. 2), government should develop strategies to cope with inequality and bring back confidence in the country.

The level of unemployment is relatively high and among the highest in West Africa and one of the sources of political instability. The civil war that erupted in 2002 confirm that it was discrimination toward foreigners and immigrants who crowding out local citizens from labour markets.

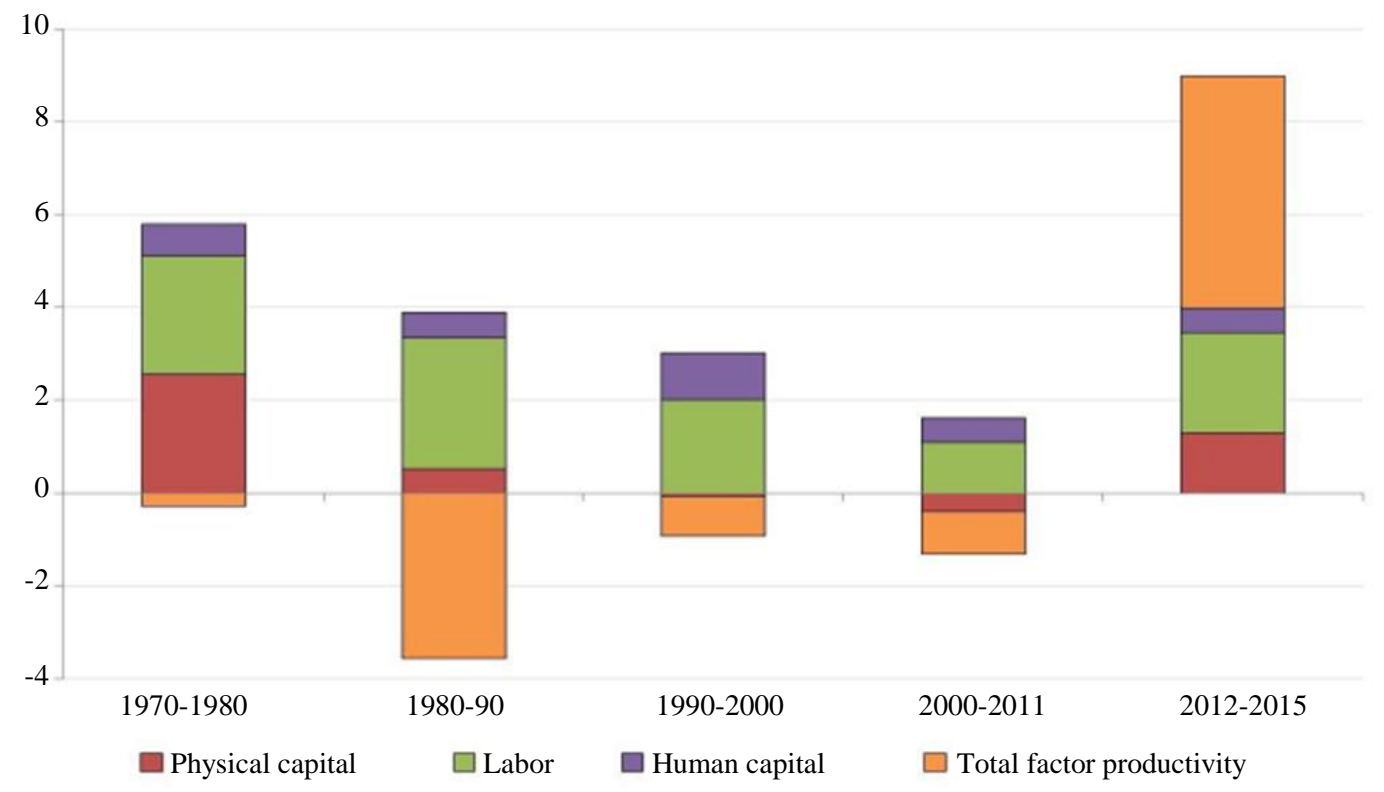

Source: IMF staff calculation

Fig. 2: Growth decomposition in Ivory Coast

Table 4: Cross-section OLS estimation

\begin{tabular}{lll}
\hline Dependant variable: Sale growth & Estimated coefficients & Bootstrap standard error. \\
\hline Political instability (base = no obstacle) & & 0.813 \\
$\quad$ Minor obstacle & 0.242 & 0.922 \\
Moderate obstacle & $-1.861^{*}$ & 0.663 \\
Major obstacle & $-0.767^{*}$ & 0.7243 \\
Very severe obstacle & $-0.835^{* * *}$ & 0.014 \\
Experience & $0.026^{*}$ & 0.004 \\
Foreign owner & $0.008^{* *}$ & 0.002 \\
Size & $0.009^{* * *}$ & 0.009 \\
Age & $0.021^{* *}$ & 0.717 \\
constant & $18.192^{* * *}$ & \\
\hline Observation & 361 & \\
\hline R-square & 0.336 & \\
Ajusted R-square & 0.316 & \\
Root MSE & 2.320 & \\
Prob>Chi2 & 0.000 & \\
\hline Not: & &
\end{tabular}

Note: $* * * \mathrm{p}<0.01, * * \mathrm{p}<0.05, * \mathrm{p}<0.1$ 
Table 5: Treatment effect estimation

\begin{tabular}{llll}
\hline & Total sales & Coef. & Robust Std. Err. \\
\hline Average Treatment Effect (ATE) & Political instability (Obstacle vs no obstacle) & $-5.11 \mathrm{e}+08 * * *$ & $1.50 \mathrm{e}+09$ \\
Potential Outcome Means (POMEAN) & Political instability No obstacle & $4.54 \mathrm{e}+09 * * *$ & $1.37 \mathrm{e}+09$ \\
\hline
\end{tabular}

Note: $* * * \mathrm{p}<0.01, * * \mathrm{p}<0.05, * \mathrm{p}<0.1$. We control for all the covariates (experience, foreign owner, size, age)

\section{Conclusion}

This paper examined firms' performance under political instability in Ivory Coast. Using firm level data from the 2016 World Bank Enterprise Survey covering 361 firms. we estimate the impact of political instability of firms' annual sales. Our methodology is twofold. First and foremost, a cross-sectional Ordinary Least Squares with the ordered variable political instability is used to analyse the correlation and then regarding the endogeneity of the perception of political instability and the bias related, endogenous treatment-regression model is estimated to capture the causal effect of political instability. This method creates an experimental environment using nonexperimental data with control variables and allow to overcome issues related to endogeneity associated with variable "political instability".

The results indicate a negative and statistically significant relationship between political instability and firm performance. The results also indicate that firm age and top manager experience in the sector strongly determine firm performance. Indeed, these variables help firms to develop their expertise and knowledge on their activities. Moreover, size and the percentage of private foreign ownership are positively related to firm performance. Analysing the causality between political instability and firm performance, we find that firms which perceive political instability as an obstacle have $5.11 \mathrm{e}+08 \mathrm{XOF}$ less in term of annual sales than firms that consider political instability not being an obstacle during the year 2016. Results confirms previous studies on the effect of violence and political instability on firm performance (Hosny, 2018; 2020).

Based on these results, the government should work to define an appropriate solution to clean up the policy environment in order to ensure efficient and productive enterprises.

\section{Acknowledgment}

We are grateful the editor and the two anonymous reviewers for insightful comments on previous versions of this paper. All remaining errors are ours.

\section{Author's Contributions}

The three authors have actively participated in developing the original idea of the paper, collecting the data, performing the empirical estimation, interpreting the results, writing the manuscript and review the final draft.

\section{Ethics and Conflict of interest}

The data used are publicly available. The authors declare no conflict of interest.

\section{References}

Abadie, A., \& Gardeazabal, J. (2003). The economic costs of conflict: A case study of the Basque Country. American economic review, 93(1), 113-132.

Acs, Z. J., \& Audretsch, D. B. (1987). Innovation, market structure and firm size. The review of Economics and Statistics, 567-574.

Aisen, A., \& Veiga, F. J. (2011). How Does Political Instability Affect Economic. IMF Working Paper Middle East and Central Asia Departmen.

Alesina, A., Özler, S., Roubini, N., \& Swagel, P. (1996). Political instability and economic growth. Journal of Economic growth, 1(2), 189-211.

Baker, S. R., Bloom, N., \& Davis, S. J. (2016). Measuring economic policy uncertainty. The quarterly journal of economics, 131(4), 15931636.Barro, R. J. (1991). Economic growth in a cross section of countries. The quarterly journal of economics, 106(2), 407-443.

Bates, R. H., Block, S. A., Fayad, G., \& Hoeffler, A. (2013). The new institutionalism and Africa. Journal of African Economies, 22(4), 499-522.

Carmignani, F. (2003). Political instability, uncertainty and economics. Journal of Economic Surveys, 17(1), 1-54.

Cerra, V., \& Saxena, S. C. (2008). Growth dynamics: the myth of economic recovery. American Economic Review, 98(1), 439-57.

Collier, P., \& Duponchel, M. (2013). The economic legacy of civil war: firm-level evidence from Sierra Leone. Journal of Conflict Resolution, 57(1), 65-88.

Dollar, D., Hallward-Driemeier, M., \& Mengistae, T. (2005). Investment climate and firm performance in developing economies. Economic Development and Cultural Change, 54(1), 1-31.

Earle, J. S., \& Gehlbach, S. (2015). The Productivity Consequences of Political Turnover: Firm-Level Evidence from Ukraine's Orange Revolution. American Journal of Political Science, 59(3), 708-723.

Goldberg, L. G., \& Rai, A. (1996). The structureperformance relationship for European banking. Journal of Banking \& Finance, 20(4), 745-771. 
Guidolin, M., \& La Ferrara, E. (2007). Diamonds are forever, wars are not: Is conflict bad for private firms?. American Economic Review, 97(5), 1978-1993.

Hallward-Driemeier, M., \& Rijkers, B. (2011). Do crises catalyze creative destruction? Firm-level evidence from Indonesia. The World Bank.

Hosny, A. (2020). What is the Cost of Political Instability in Tunisia? Evidence from 592 Private Firms. African Journal of Economic Review, 8(3), 1-19.

Hosny, A. (2018). Firm Performance and their Perception of Political Instability in Egypt: Evidence from an Endogenous Treatment Regression Model. Journal of African Development, 20(2), 61-68.

Jong-A-Pin, R. (2009). On the measurement of political instability and its impact on economic growth. European Journal of Political Economy, 25(1), 15-29.

Klapper, L., Richmond, C., \& Tran, T. (2013). Civil conflict and firm performance: evidence from Cote d'Ivoire. The World Bank.

Ksoll, C., Macchiavello, R., \& Morjaria, A. (2010). The effect of ethnic violence on an export-oriented industry.
Makhija, M. (2003). Comparing the resource-based and market-based views of the firm: empirical evidence from Czech privatization. Strategic management journal, 24(5), 433-451.

Overland, J., Simons, K. L., \& Spagat, M. (2005). Political instability and growth in dictatorships. Public Choice, 125(3-4), 445-470.

Pallage, S., Robe, M. A., \& Bérubé, C. (2006). The potential of foreign aid as insurance. IMF Staff papers, 53(3), 453-475.

Petracco, C., \& Schweiger, H. (2012). The Impact of Armed Conflict on Firms' Performance and Perceptions. European Bank for Reconstruction and Development Working Paper, 152.

Terza, J. V. (1998). Estimating count data models with endogenous switching: Sample selection and endogenous treatment effects. Journal of econometrics, 84(1), 129-154.

Schumpeter, J. A. (1976). Capitalism, socialism and democracy (1942). J. Econ. Literature, 20, 1463.

Söderbom, M., Teal, F., \& Wambugu, A. (2002). Does firm size really affect earnings?

\section{Appendix}

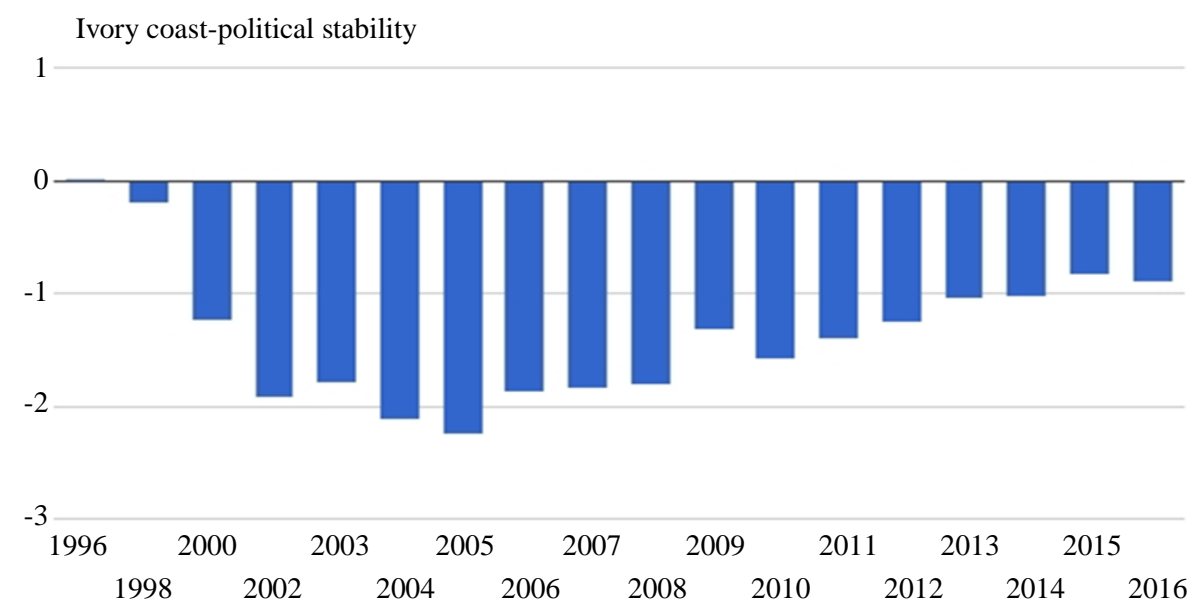

Source: TheGlobalEconomy.com, The Word Bank

Fig. 1: Political stability Histogram 